\title{
TAMPILAN FERNING PRE - POST INSEMINASI BUATAN BERDASARKAN UMUR SAPI SIMPO F1 DAN F2 DI KECAMATAN PATEAN, KABUPATEN KENDAL, JAWA TENGAH
}

(Ferning Performance Of Pre - Post Artificial Insemination Based On Age Of SIMPO F1 And F2 At Patean, Kendal, Central Java)

\author{
Andini, N. A. ${ }^{1}$, E. T. Setiatin ${ }^{2}$ dan Sutopo ${ }^{3}$ \\ 1) Mahasiswa Fakultas Peternakan Dan Pertanian Universitas Diponegoro \\ Kampus drh. Soejono Koesoemowardojo Tembalang Semarang 50275 \\ E-mail: nurulayuandini@gmail.com; etsetiatin@gmail.com \\ ${ }^{2,3}$ )Fakultas Peternakan dan Pertanian, Universitas Diponegoro \\ Kampus drh. R. Soejono Kusumowardojo Tembalang, Semarang 50275
}

Diterima : 15 Desember 2015

Disetujui : 25 Juni 2016

\begin{abstract}
The research was conducted to learn about ferning SIMPO F1 and F2 by age at district Patean, Kendal of Central Java. The material used in the study were 20 cows SIMPO, 7 SIMPO F1 and 13 SIMPO F2. Cervical mucus method of making pillowcase using vaginal, collected taken every six hours a day. Cervical mucus obtained by applying swab stick was above the object glass, aired dried the observed eith the aid of a microscope with a magtification of 10x10. Ferning performance varies SIMPO F1 and F2. Ferning scored evaluated based that on visible and tangible from of fern. The result of the test observation and desricption could conclude that performance ferning, abundance, and consistency of cervical mucus 20 SIMPO F1 and F2 cows.
\end{abstract}

Keywords: cervical musuc; abundance; consistency; female SIMPO cows.

\begin{abstract}
ABSTRAK
Penelitian ini bertujuan untuk mengetahui tampilan ferning sapi betina SIMPO F1 dan F2 berdasarkan umur di Kecamatan Patean, Kabupaten Kendal, Jawa Tengah. Materi yang digunakan dalam penelitian adalah 20 ekor sapi betina SIMPO, masing-masing 7 ekor SIMPO F1 dan 13 ekor SIMPO F2 milik peternak rakyat. Metode pengambilan lendir serviks menggunakan ulas vagina, dikoleksi sebanyak 6 jam sekali dalam 24 jam, dengan menggunakan cotton bud. Parameter yang diamati meliputi tampilan ferning, kelimpahan dan konsistensi lendir serviks. Gambaran ferning diperoleh dengan cara mengoleskan lendir serviks di atas object glass, dikeringudarakan kemudian diamati dengan bantuan mikroskop dengan perbesaran 10x10. Gambaran tampilan ferning sapi betina SIMPO F1 dan F2 bervariasi, berupa cabang primer, sekunder dan tersien. Kemudian dievaluasi berdasarkan skoring. Gambaran terlihat lebih jelas dan nyata membentuk daun pakis. Hasil uji observasional dan deskriptif dapat disimpulkan bahwa tampilan ferning, kelimpahan dan konsistensi berbeda pada 20 SIMPO F1 dan F2.
\end{abstract}

Kata kunci: lendir serviks, kelimpahan, konsistensi, sapi SIMPO betina. 


\section{PENDAHULUAN}

Kemampuan produksi sapi peranakan ongole (PO) yang dinilai masih rendah maka pemerintah berupaya mendatangkan sapi-sapi Bos taurus seperti Limousin dan Simmental untuk dikawinkan dengan sapi lokal menggunakan teknologi inseminasi buatan (IB). Sapi Simmental Peranakan Ongole (SIMPO) merupakan hasil persilangan antara sapi Simmental dengan sapi PO. Namun peningkatan produksi sapi SIMPO diduga tidak diikuti dengan peningkatan kemampuan reproduksi. Reproduksifitas sapi dapat ditingkatkan apabila siklus berahi teramati dan tercatat dengan baik. Salah satu upaya yang dapat dilakukan adalah dengan cara mendeteksi tanda-tanda berahi. Lendir serviks dapat digunakan untuk mendeteksi berahi, tipologi ferning lendir serviks akan memberikan gambaran yang berbeda-beda sesuai dengan periode siklus berahi. Penelitian ini bertujuan mengetahui perbandingan tampilan berahi dan kualitas lendir serviks (ferning) berdasarkan umur pada sapi SIMPO F1 dan F2. Manfaat dari penelitian ini adalah memberikan informasi kepada peternak tentang tampilan reproduksi sapi peranakan SIMPO saat berahi.

\section{MATERI DAN METODE}

\section{Materi}

Materi yang digunakan dalam penelitian adalah 20 ekor sapi SIMPO betina terdiri dari 7 ekor F1 dan 13 ekor F2 milik peternak rakyat. Kisaran umur ditentukan berdasarkan pada poel gigi. Alat dalam penelitian ini adalah mikroskop, kotak penyimpanan preparat lendir serviks, dan object glass, cotton bud, hands glove, kamera, kertas label dan alat tulis.

\section{Metode}

Pendataan dan wawancara dengan peternak dilakukan guna menentukan jenis ternak, umur, siklus berahi dan kondisi saluran reproduksi dari tenak sapi tersebut. Informasi terakhir kali ternak dikawinkan. Parameter yang diamati adalah, kondisi lendir serviks berupa kelimpahan dan konsistensi. Pengamatan ferning diamati melalui ciri-ciri dari tampilan ferning serta membandingkan gambaran ferning sapi SIMPO F1 dan F2 berdasarkan umur ternak. Pengamatan penelitian dilaksanakan selama 6 jam sekali selama 24 jam, dari mulai sebelum di IB dan setelah di IB (pada kondisi berahi).

Setelah lendir didapatkan kemudian dioleskan pada gelas objek untuk dibuat preparat ulas, diamati di bawah mikroskop dengan perbesaran 10x10. Pengambilan gambar dengan menggunakan kamera dengan ketajaman 8 megapixel. Pengamatan mikroskopis meliputi: gambaran karakteristik miroskopik lendir serviks sapi SIMPO F1 dan F2, dilakukan di lokasi penelitian Kecamatan Patean, Kabupaten Kendal dan Laboraturium Genetika, Pemuliaan dan Reproduksi, Fakultas Peternakan dan Pertanian, Universitas Diponegoro.

\section{Analisis Data}

Data yang diperoleh dikelompokan dan dianalisis sesuai dengan umur ternak dan generasi ternak F1 dan F2. Analisis data dilakukan dengan cara deskriptif yaitu memaparkan, menjelaskan dan mengelompokkan tampilan gambaran ferning pada lendir serviks sapi SIMPO 
generasi F1 dan F2 berdasarkan umur di Kecamatan Patean, Kabupaten Kendal.

\section{HASIL DAN PEMBAHASAN}

\section{Kondisi Lendir Serviks Sapi SIMPO F1 dan F2}

\section{Kelimpahan Lendir Seviks}

Lendir serviks pada sapi SIMPO F1 dan F2 memiliki karakteristik yang sama bersifat bening dan transparan (Ilustrasi 1). Hal ini menggambarkan bahwa ternak berada pada fase berahi. Dikemukakan oleh Partodihardjo (1992) bahwa pada fase berahi lendir serviks yang disekresikan menjadi lebih banyak dan memiliki sifat bening, tembus pandang dan dapat mengaliri hingga vagina hingga vulva. Berdasarkan Tabel 1 terlihat kelimpahan dan konsistensi dengan skor yang berbeda. Hasil penelitian menunjukkan bahwa pengambilan data pada setiap jamnya tidak menunjukkan intensitas konsistensi dan kelimpahan lendir serviks yang berbeda. Pada Tabel 1 sapi SIMPO F1 pada sapi (umur 5 tahun) memperlihatkan konsistensi dan kelimpahan yang baik. Hal ini dikarenakan semakin tua umur ternak semakin baik pula memperlihatkan tandatanda berahi. Silaban et al. (2012) menyatakan lendir serviks yang berlebihan dapat memudahkan untuk mengetahui tanda-tanda berahi.

Tabel 1. Perubahan Kelimpahan dan Konsistensi Lendir Serviks Sapi SIMPO F1 dan F2

\begin{tabular}{|c|c|c|c|c|c|c|c|c|c|}
\hline \multirow[t]{2}{*}{ No } & \multirow{2}{*}{$\begin{array}{c}\text { Filial/ Umur } \\
\text { (Tahun) }\end{array}$} & \multicolumn{4}{|c|}{ Kelimpahan } & \multicolumn{4}{|c|}{ Konsistensi } \\
\hline & & I & II & III & IV & I & II & III & IV \\
\hline & & & & . & & & ..... & & \\
\hline 1 & $\mathrm{~F} 1 / 2$ & + & + & - & - & + & + & - & - \\
\hline 2 & $\mathrm{~F} 1 / 4$ & + & - & - & + & + & - & - & + \\
\hline 3 & $\mathrm{~F} 1 / 5$ & ++ & + & - & - & ++ & + & - & - \\
\hline 4 & F1/ 6 & + & + & + & - & + & + & + & - \\
\hline 5 & $\mathrm{~F} 2 / 2$ & - & - & - & - & - & - & - & - \\
\hline 6 & $\mathrm{~F} 2 / 4$ & + & + & - & + & + & + & - & + \\
\hline 7 & F2/ 5 & + & + & - & - & + & + & - & - \\
\hline 8 & F2/ 6 & + & + & - & - & + & + & - & - \\
\hline
\end{tabular}

Keterangan : (-) : tidak terdapat kelimpahan dan konsistensi; (+) : pada lendir kelimpahannya terlihat di dalam vulva, pada lendir konsistensi sangat encer; (++): pada lendir kelimpahannya terlihat di luar vulva, pada lendir konsistensi kental; (+++): pada lendir kelimpahannya terlihat hingga meluber/ banyak sekali, pada lendir konsistensi sangat kental

\section{Konsistensi Lendir Serviks}

Konsistensi lendir serviks akan berbeda pada setiap fase berahi yang berlangsung selama satu siklus berahi di bawah pengaruh hormon estrogen. Pada Tabel 1 menunjukkan bahwa konsistensi dan kelimpahan SIMPO lendir serviks yang disekresikan bersifat sangat encer, bening dan transparan selama fase berahi. Lendir serviks akan memiliki konsistensi yang cenderung lebih kental, lengket dan berwarna agak keruh setelah fase berahi terlewati. Konsistensi lendir serviks akan berbeda pada setiap fase berahi yang berlangsung selama satu siklus berahi di bawah pengaruh hormon estrogren. Perubahan tersebut menyebabkan sel menjadi lebih sensitif sehingga ukuran sel menjadi lebih kecil akibat perubahan kadar air dalam sel (Dewantiningrum, 2008). 
Perbedaan skor konsistensi juga dipengaruhi oleh konsentrasi protein dan fosfolipid dalam lendir serviks (Mardiati, 2003).

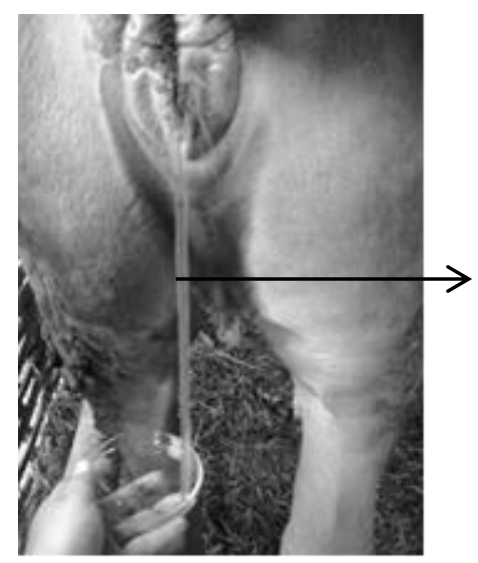

Lendir

Serviks

Ilustrasi 1. Lendir Serviks Sapi SIMPO

\section{Kualitas Ferning Lendir Serviks}

Ax et al. (2000) menyatakan bahwa lendir serviks muncul pada saat estrus dan berbentuk kristal seperti pohon pakis apabila sudah mengalami pengeringan yang diletakkan pada object glass. Skor ferning yang muncul ditandai dengan adanya ferning pada bidang pandang yang terlihat batang primer, sekunder dan tersien. Beshay and Bruce (2011), menyatakan bahwa jika diperiksa lendir serviks akan menampilkan karakteristik atau daun palem. Hasil pengamatan terdapat skor 3, skor 4 dan skor 5 pada ferning (Ilustrasi 2). Sapi SIMPO F1 dengan kode S2 menunjukkan skor 5 pada pengambilan enam jam pertama dan skor 3 pada pengambilan enam jam ke empat. Sama halnya dengan sapi S3 dan S4, tetapi pada sapi S5 dapat menunjukkan skor 4 pada pengambilan enam jam pertama dan skor 3 pada enam jam ke dua. Kondisi seperti ini dapat dimungkinkan bahwa ternak sudah melewati waktu ovulasi.

Soeharto (2003) menyatakan bahwa keberadaan ferning sangat berkaitan dengan produksi estrogen yang bertanggung jawab munculnya ferning sesaat sebelum sel telur diovulasikan. Lendir serviks merupakan lendir yang disekresikan oleh serviks yang merupakan salah satu bagian dari uterus (Hafez, 2000). Ilustrasi 2 dapat dilihat skor ferning dan gambaran ferning pada sapi SIMPO. Skor ferning yang menurun menunjukkan bahwa terjadi penurunan konsentrasi hormon estrogen dan siklus reproduksi sapi memasuki fase awal metestrus. Sapi generasi F2 hanya 3 ekor yang menunjukkan gambaran daun pakis.Sapi S8 dan sapi S9 menunjukkan gambaran skor 4 pada enam jam pertama dan skor 3 pada enam jam kedua. Pada sapi S10 hanya menunjukkan ferning dengan skor 3.

Hal tersebut tidak menunjukkan hasil yang sempurna pada skor gambaran ferning dalam setiap jam pengambilan lender serviks, karena pada saat pengambilan hal ini dikarenakan kondisi lendir serviks skor yang berbeda. Gundongan (2009) menyatakan bahwa tanda-tanda berahi maupun berahi dapat diketahui melalui karakteristik dari ferning dihasilkan dengan cara sekresi lendir serviks. Kondisi ferning sapi SIMPO F1 dan F2 yang menunjukkan hasil baik adalah yang berumur 5 tahun. Menurut Wijayanti (2014) semakin tua umur ternak maka semakin jelas tandatanda berahi yang ditunjukkan. Gambaran ferning dipengaruhi adanya kadar hormon estrogen dalam darah. Silaban et al. (2012) menyatakan bahwa ferning lendir serviks yang sempurna akan membentuk gambaran ferning seperti cabang-cabang berupa daun pakis dan hal ini dapat dijadikan kategori bahwa sapi tersebut dalam kondisi sedang berahi atau tidak. Ax et al. (2000) menyatakan bahwa ferning terjadi pada saat sapi mendekati berahi yang membentuk gambaran seperti daun pakis atau berbentuk kristal. 
Ilustrasi 2. Skor Ferning dan Gambaran Ferning Sapi SIMPO F1 dan F2

\begin{tabular}{|c|c|c|c|c|c|}
\hline No & Kode & Filial/Umur & \multicolumn{3}{|c|}{ Skor Gambaran Ferning } \\
\hline & & ...(Tahun)... & 3 & & 5 \\
\hline 1 & $\mathrm{~S} 2$ & $\mathrm{~F} 1 / 4$ & & & \\
\hline 2 & S3 & $\mathrm{F} 1 / 5$ & & & \\
\hline 3 & S4 & $\mathrm{F} 1 / 5$ & & & \\
\hline 4 & S5 & $\mathrm{F} 1 / 5$ & & & \\
\hline 5 & S6 & $\mathrm{F} 1 / 6$ & & & \\
\hline 6 & S8 & $\mathrm{F} 2 / 4$ & & & \\
\hline 7 & S9 & $\mathrm{F} 2 / 5$ & & & \\
\hline 8 & S10 & $\mathrm{F} 2 / 6$ & & & \\
\hline
\end{tabular}

KESIMPULAN DAN SARAN

\section{Kesimpulan}

Berdasarkan hasil pengamatan yang telah dilakukan dapat disimpulkan bahwa rata - rata kualitas lendir serviks berahi sapi SIMPO F2 lebih rendah dibandingkan sapi SIMPO F1. Gambaran ferning yang 
sempurna ditunjukkan oleh sapi SIMPO F1 dengan kisaran umur 4,5- 5 tahun.

\section{Saran}

Berdasarkan hasil penelitian
disarankan bahwa pemeliharaan sapi
SIMPO F2 sebaiknya tidak digunakan
untuk menghasilkan anakan. Hal ini
dikarenakan kualitas tampilan berahi sapi
SIMPO F2 menurun dibandingkan sapi
SIMPO F1.

\section{DAFTAR PUSTAKA}

Ax, R. L., M. Dally, B. A. Didion, R.W. Lenz, C. C. Love, D. D. Varue, B. Hafez, and M. E. Bellin. 2000. Cervical Mucus, In : B. Hafez, and E. S. E. Hafez (Eds.). Reproduction In Farm Animals. 7th Ed. Lippincot Williams \& Wilkins. Philadelphia.

Beshay, V. E., M. Dally, B. A. Didion, R. W. Lenz, C. C. Love, D. D. Varue, B. Hafez, and M. E. Bellin. 2000. Cervical Mucus, In : B. Hafez, and E. S. E. Hafez (Eds.). Reproduction In Farm Animals 7th Ed. Lippincot Williams \& Wilkins. Philadelphia.

Dewantiningrum, J. 2008. Perbedaan Pengaruh Clomiphene Citrate dan Letrozole terhadap Folikel, Endometrium dan Lendir Serviks Uji Klinik pada Wanita Infertil dengan Siklus Haid Tidak Teratur. Tesis. Magister Ilmu Biomedik dan Program Pendidikan Dokter Spesialis I Ilmu Obstetri dan Ginekologi).Program Pasca Sarjana, Universitas Diponegoro.

Gundogan, M. 2009. Ovulatory follicle size and mucus ferning level in relation to non-return rate during artificial insemination time in spontaneously oestrus signed cows. F.U. Sag. Bil. Vet. Derg 23 (1) : 9-13.
Hafez, E. S. E., and B. Hafez. 2000. Transport and Survival of Gamet. In : B. Hafez and E. S. E. Hafez (Eds.). Reproduction in Farm Animals. 7th Ed. Lippicott Williams and Wilkins, Philadelpia.

Mardiati, S. M. 2003. Kadar Garam Na Lendir Serviks serta Kadar Garam $\mathrm{Na}$ dan $\mathrm{K}$ Lendir Mulut pada Berbagai Struktur Daun Pakis. Tesis. Magister Ilmu Biomedik. Program Pasca Sarjana, Universitas Diponegoro.

Silaban, N. L., E. T. Setiatin dan Sutopo. 2012. Tipologi ferning sapi Jawa Brebes betina berdasarkan periode estrus. Jurnal Animal Agriculture, 1(1) : 777-788.

Siswati, E. 2014. Tampilan Berahi Peranakan Ongole dan Sapi Simmental-Peranakan Ongole berdasarkan Gambaran Ferning Serviks dan Saliva Sapi di Kecamatan Pulokulon Kabupaten Grobogan. Skripsi. Fakultas Peternakan dan Pertanian. Universitas Diponegoro. Semarang.

Suharto, K. 2003. Penampilan Potensi Reproduksi Sapi Perah Friesian Holstein Akibat Pemberian Kualitas Ransum Berbeda dan Infusi Larutan Iodium Povidon 1\% Intra Uterin. Tesis .Magister Ilmu Ternak. Program Pasca Sarjana, Universitas Diponegoro.

Wijayanti, D. 2014. Pemberian Larutan Daun Binahong Dalam Memperpendek Fase Involusi Uterus Kambing Peranakan Etawah Berdasarkan Tipologi Ferning Serviks dan Saliva. Skripsi. Universitas Diponegoro, Semarang. 